\title{
Keefektifan Model Problem Based Learning Dengan Pendekatan Problem Posing- Solving dalam Pembelajaran Matematika
}

\author{
Agusalim Juhari ${ }^{1}$, Isma Muthahharah $^{2}$ \\ ${ }^{1,2}$ Prodi Pendidikan Matematika, STKIP Pembangunan Indonesia \\ agusalimjuhari@gmail.com
}

\begin{abstract}
ABSTRAK
Tujuan penelitian ini adalah untuk melihat keefektifan Model PBL dengan pendekatan Problem Posing-Solving (PPS) yang secara khusus mendeskripsikan tentang: (a) hasil belajar Matematika siswa, (b) aktivitas siswa, dan (c) respons siswa. Metode penelitian yang akan digunakan adalah penelitian praeksperimen dengan satu kelas sebagai kelas eksperimen. Model belajar yang yang digunakan adalah model belajar dalam jaringan (daring) guna mencegah penyebaran Covid 19. Instrumen yang digunakan adalah lembar observasi aktivitas siswa, lembar observasi model keterlaksanaan pembelajaran, lembar angket respon siswa, dan tes hasil belajar dalam bentuk online-form. Data aktivitas siswa dan respons siswa dianalisis menggunakan persentase sedangkan data hasil belajar siswa dianalisis menggunakan analisis deskriptif dan analisis inferensial. Hasil Penelitian menunjukkan bahwa (1) Rata-rata skor hasil belajar (posttest) mencapai 78,93 dari skor ideal 100 dengan standar deviasi 12,5 melebihi KKM (70). Peningkatan hasil belajar berada pada kategori minimal sedang dengan rata-rata mencapai 0,75 dari skor ideal 1, (2) Aktivitas siswa berada pada kategori baik dengan skor rata-rata mencapai 3,18 dari skor 4, (3) Respons siswa berada pada kategori positif dengan skor rata-rata siswa mencapai 3,6 dari skor 4, dan (4) Model Problem based Learning dengan Pendekatan Problem Posing-Solving, efektif untuk indikator Hasil Belajar, Aktivitas Siswa, dan Respons Siswa.
\end{abstract}

Katakunci: Efektivitas, problem based learning, problem posing-solving, pembelajaran Matematika

\begin{abstract}
The purpose of this research is to see the effectiveness of the PBL Model with the Problem Posing-Solving (PPS) approach which specifically describes : (a) student mathematics learning outcomes, (b) student activities, and (c) responses students. The research method used is preexperimental research with one class. The learning model used is an online learning model to prevent the spread of Covid 19. The instruments used were student activity observation sheets, learning implementation model observation sheets, student response questionnaires, and online-form learning outcomes tests. Student activity data and student responses were analyzed using percentages, while data on student learning outcomes were analyzed using descriptive analysis and inferential analysis. The results showed that (1) The average score of learning outcomes (posttest) reached 78.93 out of the ideal score of 100 with a standard deviation of 12.5 exceeding the minimum criteria (70). The increase in learning outcomes is in the moderate minimum category with an average of 0.75 from the ideal score 1 , (2) Student activity is in the good category with an average score of 3.18 from a score of 4, (3) Student responses are at positive category with the average score of students reaching 3.6 out of 4, and (4) the Problem-based Learning Model with the Problem Posing-Solving Approach is effective for indicators of Learning Outcomes, Student Activities, and Student Responses.
\end{abstract}

Keywords: Effectiveness, problem based learning, problem posing-solving, Mathematics learning

\section{PENDAHULUAN}

Tujuan pembelajaran matematika yang diterapkan Departemen Pendidikan Nasional, sejalan dengan National Council of Teacher Mathematics (NCTM), yakni menetapkan lima kompetensi pokok: pemecahan masalah matematis (mathematical solving), komunikasi matematis (mathematical communication), penalaran matematis (mathematical reasoning), koneksi matematis (mathematical connection), 
dan representasi matematis (mathematical representation) (Kurniati et al., 2016; Dafik \& Lestari, 2014)

Matematika merupakan ilmu pengetahuan yang diperoleh dari hasil pemikiran manusia yang berhubungan dengan ide, proses, dan penalaran. Pembelajaran Matematika adalah pondasi dan Kerangka Ilmu Pengetahuan dan Teknologi (Aras \& Juhari, 2020). Pembelajaran matematika adalah proses interaksi dua arah antara guru dan peserta didik atau dua kegiatan yang dapat menentukan hasil belajar matematika (Widodo \& Kadarwati, 2013).

Pendekatan Problem Posing dan pendekatan Problem Solving adalah dua diantara banyak pendekatan pembelajaran yang melibatkan interaksi guru dan aktivitas siswa dalam proses pembelajarannya. Pendekatan Problem Solving mempunyai pengertian sebagai proses pembelajaran yang menuntut siswa untuk menyelesaikan masalah, yang bisa dibuat-buat sendiri oleh pendidik ataupun fakta nyata yang ada di lingkungan. Sedangkan, pendekatan Problem Posing adalah pembelajaran yang menekankan pada siswa untuk membentuk/mengajukan soal berdasarkan informasi atau situasi yang diberikan. Informasi yang ada diolah dalam pikiran dan setelah dipahami, maka peserta didik akan bisa mengajukan pertanyaan (Herawati et al., 2010)

Kedua pendekatan pembelajaran ini menitikberatkan pada Problem based Learning (PBL). PBL mengajak siswa diajak untuk aktif sehingga informasi tidak hanya dari guru, tetapi siswa juga dituntut untuk mengkonstruksi sendiri pengetahuan baru mereka dengan informasi atau pengetahuan mereka sebelumnya. Hanya saja, pada pendekatan pembelajaran Problem Solving, masalah yang diajukan berasal dari guru, sedangkan pada pendekatan pembelajaran Problem Posing, masalah yang diajukan berasal dari siswa sendiri.

Xia et al. (2008) menegaskan bahwa pembelajaran yang melibatkan aktivitas Problem Solving dan Problem Posing dapat menimbulkan ketertarikan siswa terhadap matematika, meningkatkan kemampuan mereka dalam mengajukan masalah dan meningkatkan kemampuan belajar matematika mereka dengan baik. Dengan demikian, Penerapan PBL dengan pendekatan Problem posing-solving (PPS) diharapkan dapat meningkatkan aktivitas dan hasil belajar Matematika Siswa
Pertanyaan yang kemudian segera untuk dijawab adalah 1) Bagaimana (a) hasil belajar matematika, (b) aktivitas, dan (c) respons siswa yang diajar melalui penerapan Model PBL dengan pendekatan PPS? dan 2) Apakah Model PBL dengan pendekatan PPS efektif dalam pembelajaran Matematika?

Secar umum, tujuan yang ingin dicapai dalam penelitian ini adalah untuk melihat keefektifan Model PBL dengan pendekatan PPS yang secara khusus mendeskripsikan tentang hasil belajar matematika, (b) aktivitas, dan (c) respons siswa .

Problem based Learning dalam Matematika mementingkan adanya kegiatan problem solving yang terdiri dari 4 langkah; (1) memahami masalah, (2) merencanakan strategi pemecahan masalah, (3) melaksanakan strategi pemecahan masalah, dan (4)mengecek kembali hasil penyelesaian. Namun demikian, pemecahan masalah saja belumlah cukup. Peserta didik masih membutuhkan hal lain yang tak kalah pentingnya, yaitu dapat mengajukan sendiri masalah/soal. Banyak peserta didik mampu melaksanakan 4 langkah dari problem solving, tetapi masih cenderung meniru dari apa yang telah ada sebelumnya. Tidak muncul kreasi yang datang dari dirinya sendiri. Dengan mengajukan masalah baru, peserta didik diharapkan berpikir lebih kritis. Oleh karena itu, perlu kajian mendalam untuk melihat bagaimana kefektifan Model PBL dengan pendekatan PPS. Temuan penelitian ini diharapkan berkontribusi pada Hasil Pembelajaran Matematika secara khusus, dan Hasil Pendidikan secara umum dalam pembentukan karakter bangsa

\section{Problem based Learning}

Pengajaran berdasarkan masalah ini telah dikenal sejak zaman John Dewey. Menurut Dewey (dalam Trianto, 2009) belajar berdasarkan masalah adalah interaksi antara stimulus dan respon, merupakan hubungan antara dua arah belajar dan lingkungan. Lingkungan memberikan masukan kepada peserta didik berupa bantuan dan masalah, sedangkan sistem saraf otak berfungsi menafsirkan bantuan itu secara efektif sehingga masalah yang dihadapi dapat diselidiki, dinilai, dianalisis, serta dicari pemecahannya dengan baik.

Model Problem based Learning (problem-based learning / PBL) adalah konsep pembelajaran yang membantu guru menciptakan lingkungan pembelajaran yang dimulai dengan masalah yang penting dan 
relevan (bersangkut-paut) bagi peserta didik, dan memungkinkan peserta didik memperoleh pengalaman belajar yang lebih realistik (nyata)

\section{Langkah-langkah Problem based Learning}

Menurut Fogarty (1997) Proses belajar mengajar dimulai dengan masalah yang tidak terstruktur (sesuatu yang kacau). Dari kekacauan ini siswa menggunakan berbagai kecerdasannya melalui diskusi dan penelitian untuk menentukan isu nyata yang ada. Langkah-langkah yang akan dilalui oleh siswa dalam sebuah proses PBL menurut David Johnson \& Jhonson melalui kegiatan kelompok adalah :

a. Mendefinisikan masalah. Merumuskan masalah dari peristiwa tertentu yan mengandung konflik hingga siswa jelas dengan masalah yang dikaji. Dalam hal ini guru meminta pendapat siswa tentang masalah yang sedang dikaji.

b. Mendiagnosis masalah, yaitu menentukan sebab-sebab terjadinya masalah.

c. Merumuskan alternatif strategi. Menguji setiap tindakan yang telah dirumuskan melalui diskusi kelas.

Tabel 1 Langkah-langkah Model Problem based Learning

\begin{tabular}{|c|c|}
\hline Tahap/ Fase & Tingkah Laku Guru \\
\hline $\begin{array}{l}\text { Tahap-1 } \\
\text { Orientasi siswa pada masalah }\end{array}$ & $\begin{array}{l}\text { Guru menjelaskan tujuan pembelajaran, menjelaskan logistik } \\
\text { yang dibutuhkan, mengajukan fenomena atau demonstrasi atau } \\
\text { cerita untuk memunculkan masalah, memotivasi siswa untuk } \\
\text { terlibat dalam pemecahan masalah yang dipilih. }\end{array}$ \\
\hline $\begin{array}{l}\text { Tahap-2 } \\
\text { Mengorganisasi siswa untuk belajar }\end{array}$ & $\begin{array}{l}\text { Guru membantu siswa untuk mendefinisikan dan } \\
\text { mengorganisasi tugas belajar yang berhubungan dengan } \\
\text { masalah tersebut }\end{array}$ \\
\hline $\begin{array}{l}\text { Tahap-3 } \\
\text { Membimbing penyelidikan individual } \\
\text { maupun kelompok }\end{array}$ & $\begin{array}{l}\text { Guru mendorong siswa untuk mengumpulkan informasi yang } \\
\text { sesuai, melaksanakan eksperimen untuk mendapatkan } \\
\text { penjelasan dan pemecahan masalah. }\end{array}$ \\
\hline Tahap-4 & Guru membantu siswa dalam merencanakan dan menyiapkan \\
\hline Mengembangkan dan menyajikan hasil karya & $\begin{array}{l}\text { karya yang sesuai seperti laporan, video, dan model serta } \\
\text { membantu mereka untuk berbagi tugas dengan temannya. }\end{array}$ \\
\hline $\begin{array}{l}\text { Tahap-5 } \\
\text { Menganalisis dan mengevaluasi proses } \\
\text { pemecahan masalah }\end{array}$ & $\begin{array}{l}\text { Guru membantu siswa untuk melakukan refleksi atau evaluasi } \\
\text { terhadap penyelidikan mereka dan proses-proses yang mereka } \\
\text { gunakan. }\end{array}$ \\
\hline
\end{tabular}

\section{Pendekatan Problem Posing Dalam Pembelajaran Matematika}

Sesuai dengan kedudukan problem posing merupakan langkah awal dari problem solving, maka pembelajaran problem posing juga merupakan pengembangan dari pembelajaran problem solving. Silver dkk (dalam Sutiarso, 2000) menyatakan bahwa dalam problem posing diperlukan kemampuan siswa dalam memahami soal, merencanakan langkah-langkah penyelesaian soal, dan menyelesaikan soal tersebut. Ketiga d. Menentukan \& menerapkan strategi pilihan. Pengambilan keputusan tentang strategi mana yang dilakukan.

e. Melakukan evaluasi. Baik evaluasi proses maupun evaluasi hasil

Model lingkungan belajar konstruktivistik tersebut memberikan landasan yang kuat dalam mendesain PBL. Proses PBL dijalankan dengan 8 langkah siswa, yaitu: (1) menemukan masalah, (2) mendefinisikan masalah, (3) mengu-mpulkan fakta - fakta, (4) menyusun dugaan sementara, (5) menyelidiki, (6) menyempurnakan permasalahan yang telah didefinisikan, (7) menyimpulkan alternativealternatif pemecahan secara kolaboratif, (8) menguji solusi permasalahan (Fogarty 1997)

Terdapat 5 langkah utama atau tahapan di dalam Problem based Learning. Dimulai dengan guru menyampaikan tujuan pembelajaran dan memotivasi siswa untuk terlibat dalam pemecahan masalah. Ibrahim \& Nur (2000) mengemukakan bahwa langkah - langkah Pembelajaran Berbasi Masalah adalah sebagai berikut 
sub pertanyaan yang relevan dengan pertanyaan guru.

c. Post solution posing yaitu siswa membuat soal yang sejenis, seperti yang dibuat oleh guru.

Problem posing merupakan masalah pokok dalam disiplin matematika dan dalam alam berpikir matematik.Karena karakteristik berpikir matematika dapat dilaksanakan dalam pembelajaran dengan problem posing.

Dalam penelitian ini, problem posing disimpulkan sebagai suatu pembentukan soal atau pengajuan soal yang dilakukan oleh siswa dengan cara membuat soal tidak jauh beda dengan soal yang diberikan oleh guru ataupun dari situasi dan pengalaman siswa itu sendiri. Dan bagi siswa, pembelajaran problem posing merupakan keterampilan mental, siswa menghadapi suatu kondisi dimana diberikan suatu permasalahan dan siswa memecahkan masalah tersebut.

\section{Pendekatan Problem Solving Dalam Pembelajaran Matematika}

Menurut Wardhani (2010) pemecahan masalah (problem solving) adalah proses menerapkan pengetahuan yang telah diperoleh sebelumnya ke dalam situasi baru yang belum dikenal. Dengan demikian ciri dari penugasan berbentuk pemecahan masalah adalah: (1) ada tantangan dalam materi tugas atau soal, (2) masalah tidak dapat diselesaikan dengan menggunakan prosedur rutin yang sudah diketahui penjawab.

Polya (dalam Hudojo, 2005) mengartikan pemecahan masalah (problem solving) sebagai suatu usaha mencari jalan keluar dari suatu kesulitan guna mencapai suatu tujuan yang tidak begitu segera dapat dicapai. Langkahlangkah (sintaks) menurut Polya dalam pembelajaran menggunakan problem solving dalam Matematika dibagi menjadi empat tahap, yaitu (1) memahami masalah, merencanakan strategi penyelesaian, (3) Melaksanakan Rencana, dan (4) Memeriksa kembali

\section{METODE PENELITIAN}

Penelitian ini adalah penelitian kuantitatif, jenis pra-eksperimen dengan tujuan untuk mengetahui efektivitas pembelajaran matematika melalui penerapan model Problem based Learning (PBL) dengan pendekatan Problem Posing-Solving (PPS). Desain penelitian ini adalah satu kelompok PretestPosttest (The One Group Pretest-Posttest Design) yang dilaksanakan menggunakan adaptasi model dalam jaringan (daring).
Aplikasi/model daring yang digunakan dalam menerapkan sintaks/langkah-langkah Model PBL dengan pendekatan PPS adalah virtual Meeting (Zoom Meeting) dan Sosial Network site (Whatsapp Group).

Populasi dalam penelitian ini adalah semua siswa kelas X SMA Negeri 17 Makassar. Pengambilan sampel dalam penelitian ini menggunakan cluster random sampling dengan langkah- langkah sebagai berikut:

1) Menetapkan populasi penelitian yaitu semua siswa kelas X SMA Negeri 17 Makassar pada semester ganjil tahun ajaran 2019/2020 yang terdiri dari enam kelas/cluster.

2) Memilih satu kelas dari enam kelas yang ada sesuai langkah a diatas.

3) Semua siswa yang terpilih pada langkah b merupakan sampel yang akan diteliti dalam penelitian ini.

Sampel yang terpilih dalam penelitian ini adalah kelas X IPA 2 yang berjumlah 33 siswa.

\section{Instrumen Penelitian}

Instrumen yang digunakan untuk mengumpulkan data adalah lembar observasi aktivitas siswa, angket respon siswa terhadap pembelajaran, lembar observasi keterlaksanaan model pembelajaran dan tes hasil belajar dalam bentuk online-form

\section{Teknik Pengumpulan Data}

Adapun teknik pengumpulan data yang peneliti gunakan dalam penelitian ini adalah sebagai berikut:

1) Hasil Belajar

Data hasil belajar dikumpulkan dengan menggunakan tes hasil belajar siswa dalam bentuk online-form. Adapun hasil belajar siswa diambil melalui tes belajar siswa sebelum dan setelah mempelajari semua materi dalam penelitian ini selesai dibahas.

2) Aktivitas Siswa

Data aktivitas siswa dikumpulkan dengan menggunakan lembar observasi keterampilan proses/aktivitas siswa selama pembelajaran daring. Aktivitas yang diukur adalah aktivitas kelompok siswa yang telah dibagi menjadi 5 kelompok pada masing-masing Whatsapp Group.

3) Respons Siswa

Data respons siswa terhadap pembelajaran dikumpulkan dengan menggunakan angket respons siswa dalam bentuk online-form setelah pemberian Tes Hasil belajar.

4) Keterlaksanaan Pembelajaran 


\begin{abstract}
Data keterlaksanaan pembelajaran dikumpulkan dengan menggunakan lembar observasi keterlaksanaan pembelajaran setiap pertemuan.
\end{abstract}

\section{Teknik Analisis Data}

Analisis statistika deskriptif digunakan untuk menganalisis data keterlaksanaan pembelajaran, aktivitas siswa selama pembelajaran, respons siswa terhadap pembelajaran, dan hasil belajar siswa. Analisis deskriptif bertujuan melihat gambaran suatu data secara umum. Analisis statistika deskriptif dimaksudkan untuk menggambarkan karakteristik faktor yang diselidiki misalnya hasil belajar siswa yang meliputi: nilai tertinggi, nilai terendah, nilai rata-rata, rentang, median, standar deviasi, dan tabel distribusi frekuensi. Selanjutnya Gain adalah selisih antara nilai Posttest dan Pretest, dilakukan menunjukkan peningkatan pemahaman atau penguasaan konsep siswa setelah pembelajaran dilakukan guru. Teknik analisis data dengan statistic inferensial digunakan menguji hipotesis penelitian. Untuk pengujian hipotesis digunakan statistic parametric dengan one samples t-Test. t-Test ini digunakan untuk menguji criteria keefektifan dari tes hasil belajar (Posttest dan N-Gain).

Kriteria keefektifan model pembelejaran mengacu pada: (1) Hasil belajar matematika siswa, (2) Aktivitas Siswa, dan (3)

HASIL \& PEMBAHASAN

\section{Hasil Penelitian}

\section{Keterlaksanaan Model $P B L$ dengan Pendekatan PPS}

Respons siswa. Secara rinci dijelaskan secara berikut:

1) Hasil belajar matematika siswa

Hasil belajar matematika siswa dikatakan efektif apabila memenuhi kriteria sebagai berikut:

a) Secara deskriptif

(1) Skor rata-rata hasil belajar siswa untuk post-test melebihi KKM (70)

(2) Rata-rata gain ternormalisi minimal berada pada kategori sedang

(3) Ketuntasan siswa secara klasikal lebih dari $85 \%$.

b) Secara inferensial

(1) Skor rata-rata hasil belajar siswa untuk posttet melebihi KKM (70)

(2) Rata-rata gain ternormalisasi minimal berada pada kategori sedang $(>0,3)$

2) Aktivitas siswa dalam pembelajaran Aktivitas siswa dikatakan efektif apabila secara deskriptif skor aktivitas siswa minimal berada pada kategori baik atau skor aktivitas siswa lebih dari 2,5

3) Respons siswa

Respons siswa dikatakan efektif apabila secara deskriptif skor respons siswa berada pada kategori positif atau skor respons siswa lebih dari 3,4

Keterlaksanaan model pembelajaran secara keseluruhan dapat dilihat dari hasil observasi pada kegiatan proses pembelajaran yang diperlihatkan pada Tabel 2

Tabel 2. Tingkat Keterlaksanan Pembelajaran (TKP) Model PBL-PPS

\begin{tabular}{ccc}
\hline Pertemuan & $\begin{array}{c}\text { Rata-rata } \\
\text { TKP }\end{array}$ & Kategori \\
\hline Pertemuan I & 3,45 & Terlaksana dengan baik \\
Pertemuan II & 3,59 & Terlaksana dengan sangat baik \\
Pertemuan III & 3,68 & Terlaksana dengan sangat baik \\
Pertemuan IV & 3,82 & Terlaksana dengan sangat baik \\
Rata-rata & 3,64 & Terlaksana dengan sangat baik \\
\hline
\end{tabular}

Berdasarkan kategorisasi TKP secara umum Model Problem based Learning dengan Pendekatan Problem Posing-Solving terlaksana dengan sangat baik.

\section{Hasil Belajar Matematika Siswa yang}

\section{diajar menggunakan Model Problem based Learning dengan Pendekatan Problem Posing-Solving (PPS)}

\section{a) Hasil Analisis Statistik Deskriptif}

Hasil belajar siswa dideksripsikan berdasarkan analisis hasil pretest dan posttest pada kelas X IPA 2 SMA Negeri 17 Makassar Materi Persamaan Eksponen (Matematika 
Peminatan). Data hasil belajar siswa selengkpanya diperlihatkan pada tabel 3 .

Tabel 3. Rekapitulasi Tes Hasil Belajar Peserta didik

\begin{tabular}{lll}
\hline \multicolumn{1}{c}{ Statistik } & Pretest & Posttest \\
\hline Mean & 15.4545 & 78.9394 \\
Std. Error of Mean & 1.14344 & 2.17605 \\
Median & 15.0000 & 77.5000 \\
Mode & 10.00 & 75.00 \\
Std. Deviation & 6.56858 & 12.50047 \\
Variance & 43.146 & 156.262 \\
Range & 22.50 & 52.50 \\
Minimum & 5.00 & 47.50 \\
Maximum & 27.50 & 100.00 \\
Sum & 510.00 & 2605.00 \\
\hline
\end{tabular}

Skor frekuensi dan persentase hasil belajar siswa yang diajar dengan menggunakan $P B L$ -
PPS jika dikelompokkan kedalam lima kategori, diperlihatkan pada tabel 4.

Tabel 4 Distribusi dan persentase skor hasil belajar Matematika siswa

\begin{tabular}{llcccc}
\hline \multirow{2}{*}{ Interval Skor } & \multirow{2}{*}{ Kategori } & Frekuensi & Persentase(\%) & Frekuensi & $\begin{array}{c}\text { Persentase } \\
(\%)\end{array}$ \\
\cline { 3 - 6 } & & 33 & 100 & 1 & 3 \\
\hline $0,00-54,9$ & Sangat Rendah & 0 & 0 & 1 & 3 \\
$55,0-64,9$ & Rendah & 0 & 0 & 16 & 48,6 \\
$65,0-79,9$ & Sedang & 0 & 0 & 8 & 24,2 \\
$80,0-89,9$ & Tinggi & 0 & 0 & 7 & 21,2 \\
$90,0-100,0$ & Sangat Tinggi & $\mathbf{3 3}$ & $\mathbf{1 0 0}$ & $\mathbf{3 3}$ & $\mathbf{1 0 0}$ \\
\hline Jumlah & & & &
\end{tabular}

Selanjutnya, frekuensi dan persentase hasil belajar Matematika siswa sebelum dan setelah diajar dengan menggunakan model $P B L-P P S$ berdasarkan Kriteria Ketuntasan
Minimal (KKM) yang berlaku di SMA Negeri 17 Makassar, maka dikelompokkan ke dalam dua kategori. Hal ini dapat dilihat pada Tabel 5.

Tabel 5. Distribusi Ketuntasan Hasil Belajar Matematika Peserta Didik

\begin{tabular}{llllll} 
& \multirow{2}{*}{ KKM } & \multicolumn{2}{l}{ Jumlah Peserta Didik } & \multicolumn{2}{l}{ Persentase Ketuntasan (\%) } \\
\cline { 3 - 6 } & \multirow{2}{*}{ Tuntas } & Tidak Tuntas & Tuntas & Tidak Tuntas \\
\hline Pretest & \multirow{2}{*}{70} & 0 & 33 & 0 & 100 \\
Posttest & 29 & 4 & 87,9 & 12,1 \\
\hline
\end{tabular}

Adapun klasifikasi peningkatan hasil belajar siswa (N-Gain Ternormalisasi) diperlihatkan pada Tabel 6.

Tabel 6. Hasil pengkategorian N-Gain Siswa

\begin{tabular}{|c|c|c|c|}
\hline Interval & Frekuensi & Persentase (\%) & Kategori \\
\hline $\mathrm{g}<0,3$ & 0 & 0 & Rendah \\
\hline $0,3 \leq \mathrm{g}<0,7$ & 12 & 36,4 & Sedang \\
\hline $\mathrm{g} \geq 0,7$ & 21 & 63,6 & Tinggi \\
\hline Rata-rata & 0,75 & & Tinggi \\
\hline
\end{tabular}

\section{b) Hasil Analisis Statistik Inferensial}

Uji hiptoesis hasil belajar (Posttest dan N-

Gain) dianalisis dengan menggunakan One Sample t-test dengan masing-masing menguji hipotesis sebegai berikut:
(1) Skor rata-rata hasil belajar siswa untuk posttet melebihi KKM (70)

$$
\begin{aligned}
H_{0}: \mu= & 69,9 \text { lawan } H_{1}: \mu>69,9 \\
\mu: & \text { parameter skor rata-rata hasil } \\
& \text { belajar matematika siswa kelas } \mathrm{X}
\end{aligned}
$$


SMA Negeri 17 Makassar setelah diajar menggunakan Model $P B L-P P S$

(2) Rata-rata gain ternormalisasi minimal berada pada kategori sedang $(>0,3)$

$H_{0}: \mu=0,29$ lawan $H_{1}: \mu>0,29$

$\mu$ : parameter skor rata-rata gain ternormalisasi siswa

Tabel 7. Uji Normalitas Data Hasil Belajar

\begin{tabular}{ccccc}
\hline & \multicolumn{2}{c}{ Kolmogorov-Smirnov } & Keterangan \\
\cline { 2 - 5 } & Statistic & df & Sig. & \\
\hline Posttest & 0.133 & 33 & 0,148 & Normal \\
N-Gain & 0.118 & 33 & 0.200 & Normal \\
\hline
\end{tabular}

Tabel 8 Uji Satu Sampel Posttest

One-Sample Test

Test Value $=69.9$

Mean

$95 \%$ Confidence Interval of the

\begin{tabular}{ccccccc} 
& & & & \multicolumn{2}{c}{ Mean } & Difference \\
& $\mathrm{t}$ & $\mathrm{df}$ & Sig. (2-tailed) & Difference & Lower & Upper \\
\hline Posttest & 4.154 & 32 & .000 & 9.03939 & 4.6069 & 13.4719 \\
\hline
\end{tabular}

Hasil uji t satu sampel untuk data posttest pada Tabel 7 menunjukkan bahwa $\frac{p \text {-value (two tailed) }}{2}=0,000<0,05=$ $\alpha$, maka $H_{0}$ ditolak. Hal ini berarti
Pengujian

hipotesis menggunakan uji t satu sampel (one sample t-test) diperlihatkan pada tabel 8 dan 9 setelah uji normalitas (kalmogorf smirnov) dilakukan. Hasil Uji Normalitas diperlihat pada tabel 7.

Tabel 9 Uji Satu Sampel N-Gain

\section{One-Sample Test}

Test Value $=0.29$

$95 \%$ Confidence Interval of the Difference

\begin{tabular}{ccccccc} 
& $\mathrm{t}$ & $\mathrm{df}$ & Sig. (2-tailed) & Mean Difference & Lower & Upper \\
\hline N-Gain & 17.937 & 32 & .000 & .46176 & .4093 & .5142 \\
\hline
\end{tabular}

Hasil uji t satu sampel untuk data $N$-Gain pada Tabel 8 menunjukkan bahwa $\frac{p \text {-value (two tailed) }}{2}=0,000<0,05=$ $\alpha$, maka $H_{0}$ ditolak. Hal ini berarti bahwa Gain ternormalisasi

3. Aktivitas Siswa Selama Pembelajaran dengan menggunakan Model Problem based Learning dengan Pendekatan Problem Posing-Solving (PPS)

Data aktivitas siswa diperoleh berdasarkan pengamatan melalui lembar observasi aktivitas siswa pada Virtual Meeting menggunakan zoom meeting dan Social Network Site menggunakan Whatsapp Group yang terdiri dari 5 (lima) kelompok/Whatsapp Group. Data yang diambil bahwa hasil belajar matematika siswa kelas X SMA Negeri 17 Makassar setelah diajar menggunakan model $P B L-P P S$ mencapai Kriteria Ketuntasan Minimal. 


\begin{tabular}{ccccccc}
\hline 2 & 3,4 & 3,4 & 3,6 & 3,8 & 3,55 & Sangat baik \\
3 & 2,6 & 3 & 3,2 & 3,8 & 3,15 & Baik \\
4 & 3 & 3 & 3,6 & 4 & 3,4 & Baik \\
5 & 2,8 & 3 & 3,6 & 4 & 3,35 & Baik \\
6 & 2,8 & 2,8 & 3 & 3,4 & 3 & Baik \\
7 & 1,8 & 2 & 2,6 & 3,4 & 2,45 & Baik \\
8 & 2 & 2,4 & 3,6 & 3,6 & 2,9 & Baik \\
\hline \multicolumn{7}{c}{ Rata-rata total } \\
\hline
\end{tabular}

Keterangan:

1: mendengarkan/memperhatikan penjelasan guru - (zoom meeting)

2: membaca buku siswa dan lembar kegiatan siswa - (zoom meeting)

3: mengumpulkan informasi yang sesuai, melaksanakan eksperimen untuk mendapatkan penjelasan dan pemecahan masalah secara berkelompok - (whatsapp group)

4: melakukan problem posing (post solution posing yaitu membuat soal yang sejenis, seperti yang dibuat oleh guru) - (whatsapp group)

5: menjawab sendiri dari soal yang dibuat (problem posing-solving)- (whatsapp group)

6: berdiskusi bersama dengan teman kelompoknya tentang hasil jawaban masing- masing (bertanya dan menanggapi) (whatsapp group)

7: mengemukakan jawaban yang dimilikinya ke muka kelas - (zoom meeting)

8: membuat rangkuman dari materi yang dipelajari - (whatsapp group)

4. Respons siswa terhadap Model

Problem based Learning (PBL) dengan Pendekatan Problem Posing-Solving (PPS)

Respons siswa dalam pembelajaran dengan model $P B L-P P S$ disajikan secara lengkap pada lampiran. Berikut data hasil kategorisasi respons siswa untuk tiap aspek yang disajikan pada Tabel 11.

Tabel 11. kategori skor rata-rata respons siswa tiap aspek

\begin{tabular}{ccc}
\hline Aspek & Rata-rata & Kategori \\
\hline 1 & 3,67 & Positif \\
2 & 3,63 & Positif \\
3 & 3,60 & Positif \\
4 & 3,51 & Positif \\
5 & 3,63 & Positif \\
6 & 3,57 & Positif \\
7 & 3,57 & Positif \\
8 & 3,57 & Positif \\
9 & 3,63 & Positif \\
10 & 3,54 & Positif \\
11 & 3,60 & Positif \\
12 & 3,48 & Cenderung Positif \\
13 & 3,78 & Positif \\
14 & 3,60 & Positif \\
15 & 3,54 & Positif \\
\hline Rata-rata & 3,6 & Positif \\
total & & \\
\hline
\end{tabular}

Keterangan:

1. Siswa senang dengan pembelajaran yang dilakukan oleh guru

2. siswa lebih termotivasi untuk belajar matematika dengan pembelajaran yang dilakukan oleh guru

3. siswa lebih memahami materi pelajaran matematika melalui pembelajaran yang dilakukan oleh guru

4. siswa lebih mudah mengingat materi pelajaran matematika melalui pembelajaran yang dilakukan oleh guru

5. lembar kegiatan/langkah-langkah pembelajaran mendukung proses belajar siswa untuk meningkatkan hasil belajar matematika

6. siswa mempunyai lebih banyak kesempatan untuk memunculkan atau menyampaikan pertanyaan/soal atau pendapat kepada siswa lain atau guru 
selama pembelajaran

7. buku siswa/PPT mendukung proses belajar siswa untuk meningkatkan hasil belajar matematika

8. siswa senang dengan suasana belajar di kelas selama kegiatan pembelajaran matematika

9. siswa senang dengan cara mengajar guru

10. siswa merasa lebih tertantang untuk mempelajari materi pembelajaran

11. siswa setuju jika pokok bahasan selanjutnya menggunakan pembelajaran matematika seperti ini

12. siswa merasakan ada kemajuan setelah pembelajaran Problem Posing (Membuat soal) dan Problem Solving (Menjawab soal)

13. pembelajaran Problem Posing-Solving memberi siswa pengalaman belajar yang lebih banyak daripada pembelajaran lainnya

14. Belajar dalam kelompok yakni membuat dan menjawab soal sendiri (beserta soal yang diberikan) ini memungkinkan siswa berdiskusi, bertukar ide, dan pikiran dengan teman kelompok

15. pengalaman bekerja dalam kelompok pada pembelajaran ini memudahkan siswa dalam mengingat pengetahuan tentang materi

\section{Pembahasan}

Model Problem based Learning dalam pembelajaran menekankan pada penguasaan konsep secara komperehensif dengan pengajuan dan pemecahan masalah. Penerapannya dalam pembelajaran menggunakan kelompok-kelompok kecil agar siswa bekerja sama dan bertanggung jawab. Dalam kelompok, siswa diberi kesempatan mengumpulkan informasi yang sesuai, melaksanakan eksperimen untuk mendapatkan penjelasan dan pemecahan masalah. Selanjutnya, siswa melakukan problem posing (post solution posing yaitu membuat soal yang sejenis, seperti yang dibuat oleh guru), kemudian memecahkannya secara bersamasama.

Hasil observasi terhadap keterlaksanaan pembelajaran dengan model $P B L-P P S$ menunjukkan peningkatan dari tiap pertemuan. Hal tersebut disebabkan pada setiap akhir pertemuan, data hasil pengamatan dievaluasi kembali sehingga perbaikan dimungkinkan untuk dilaksanakan pada pertemuan berikutnya. Pada pertemuan awal, pembentukan siswa dalam kelompok relatif lama, karena komunikasi melalui daring (dalam jaringan/online) tidak selancar luring (Luar jaringan/tatap muka langsung). Pelaksanaan model pembelajaran yang melalui Aplikasi Zoom Meeting berbantuan Whatsapp Group menghasilkan 5 kelompok/whatsapp group yang masing-masing siswa bekerja bersama di dalamnya. Sehingga pada pertemuan selanjutnya, pembagian kelompok cukup dengan mengikuti kembali kelompok yang sudah dibentuk dipertemuan selanjutnya.

Hal yang menjadi baru dalam kegiatan pembelajaran ini adalah pengajuan masalah oleh siswa sendiri. selain itu, setelah mengajukan masalah, siswa dituntut kembali memecahkan masalahnya dengan langkahlangkah polya, yang terdiri dari (a) see, (b) plan, (c) do, dan (d) looking back. Hal tersebut membuat siswa sedikit kebingungan di awal pertemuan karena masih belum terbiasa belajar mengemukakan masalah sendiri. Siswa pada umumnya, selalu mengharapkan penjelasan guru terkait materi, kemudian menunggu masalah yang diberikan oleh guru untuk dikerjakanannya, baik dengan memahami konsep dengan benar atau hanya mengikuti/menyalin dari pekerjaan temannya. pada pertemuan-pertemuan berikutnya, siswa mulai terbiasa dalam megajukan masalah, mendiskusikan bentuk masalah dan cara pemecahan masalahnya dengan sesama teman kelompok. Sebagian besar siswa telah mampu menguasai dan memahami bagaimana megajukan masalah dan memecahkannya dengan langkah-langkah polya, sehingga suasana pembelajaran lebih baik dan teratur.

Dalam Model PBL-PPS, siswa dituntut berperan aktif di kelompok masing-masing. Aktivitas siswa di dalam Group adalah berupa membagikan hasil pengajuan dan pemecahan masalah, berdiskusi dengan cara chatting atau melakukan panggilan video untuk sama membahas pecahan masalah yang telah diposting.

Adapun sedikit hambatan yang dialami pada penelitian ini adalah jaringan internet yang kadang-kadang tidak memadai. Pemilihan metode daring dalam pelaksanaannya demi mencegah penyebaran COVID-19. Implikasi nya adalah penetepan working from home (wfh) dan learning from home (lfh) sehingga Pembelajaran dilaksanakn melaui daring. Namun, secara umum tidak ada kendala berarti dalam proses pelaksanaan penelitian. 
Berdasarkan skor pretest yang diperoleh sebelum menerapkan model PBLPPS menunjukkan bahwa tingkat kemampuan awal siswa masih berada pada tahap sangat rendah. Skor maksimum yang diperoleh siswa adalah 27,50 dari skor ideal 100. Namun, hasil belajar matematika siswa setelah diajar dengan menggunakan model PBL-PPS cenderung berada pada kategori sedang. Penerapan model pembelajaran PBL-PPS berpengaruh terhadap hasil belajar siswa, hal ini ditunjukkan dari nilai rata-rata yang diperoleh siswa pada posttest yang mencapai 78,93 dari skor ideal 100 dengan standar deviasi 12,5. Hasil belajar matematika siswa juga menunjukkan bahwa terdapat peningkatan signifikan setelah proses pembelajaran dengan model pembelajaran PBPPS. Hal tersebut ditunjukkan oleh nilai gain yang diperoleh siswa yakni 0,75 dari skor ideal 1 yang berada pada kategori tinggi. Peningkatan tersebut tidak lepas dari kompleksitas model pembelajaran berbasis masalah dengan pendekatan problem posing-solving. Hal ini sesuai dengan hasil penelitian Amiluddin \& Sugiman (2016) menyatakan bahwa problem posing dan PBL berpengaruh terhadap prestasi belajar, dan motivasi belajar mahasiswa pendidikan matematika. Hasil ini sesuai dengan pendapat Xia et al. (2008) yang menyatakan bahwa model Problem based Learning yang diterapkan memainkan peran penting dalam membangkitkan minat siswa pada matematika, meningkatkan kemampuan mereka dalam mengemukakan masalah dan juga meningkatkan kemampuan belajar matematika mereka. Dengan demikian, hasil belajar siswa dapat ditingkatkan salah satunya dengan penerapan model ini. peningkatan yang terjadi juga menyebabkan siswa mencapai ketuntasan klasikal yang diharapkan (85\%). Siswa hanya Sebagian besar siswa memperoleh nilai hasil belajar matematika yang lebih besar dari Standar Kriteria Ketuntasan Minimal yang ditetapkan (70) dan hanya sebagian kecil siswa yang memperoleh nilai hasil belajar matematika yang kurang dari dari Standar Kriteria Ketuntasan Minimal yang ditetapkan.

Hasil observasi terhadap aktivitas siswa dalam pembelajaran dengan menggunakan model PBL-PPS menunjukkan bahwa kedelapan kategori yang diamati memenuhi kriteria efektif. Skor rata-rata aktivitas siswa adalah 3,18 dari skor 4 yang berada pada kategori baik. Bentuk aktivitas siswa yang diharapkan tercapai, yaitu mendengarkan/ memperhatikan penjelasan guru, membaca buku siswa dan lembar kegiatan siswa, mengumpulkan informasi yang sesuai, melaksanakan eksperimen untuk mendapatkan penjelasan dan pemecahan masalah secara berkelompok, melakukan problem posing (post solution posing yaitu membuat soal yang sejenis, seperti yang dibuat oleh guru), menjawab sendiri dari soal yang dibuat, berdiskusi bersama dengan teman kelompoknya tentang hasil jawaban masing-masing (bertanya dan menanggapi), mengemukakan jawaban yang dimilikinya ke muka kelas, dan membuat rangkuman dari materi yang dipelajari. Pencapaian ini menunjukkan bahwa aktivitas siswa yang diharapkan terpenuhi. Hal ini sesuai dengan aktivitas yang diharapkan pada model PBL-PPS yang memberi kesempatan kepada siswa untuk mengkonstruksi sendiri pengetahuan melalui pengajuan dan pemecahan masalah sehingga konsep akan benar-benar dikuasai siswa. Hasil penelitian Shanti \& Abadi (2015) mengundikasikan bahwa pada pembelajaran yang berfokus pada pengajuan soal sendiri oleh siswa, siswa harus benar-benar menguasai konsep tertentu yang akan berdampak pada tercapainya indikatorindikator kompetensi menggunakan mengidentifikasi masalah matematika, mampu menganalisis suatu masalah yang tertuang proses pemecahan masalah, dan pada akhirnya siswa mampu menerapkan konsep yang telah diperoleh untuk kasus atau contoh-contoh lain, termasuk saat menyelesaikan latihan soal.

Hasil penelitian terhadap respons siswa dengan PBL-PPS berada pada kategori positif dengan skor rata-rata siswa mencapai 3,6 dari skor 4. Siswa merasa senang dengan pembelajaran yang dilakukan oleh guru. Hal tersebut terlihat dari aspek 1 dengan skor ratarata 3,67 yang berada pada kategori positif. Model $P B L-P P S$ pada pembelajaran matematika menjadikan pembelajaran matematika lebih bermakna dan tuntas, menciptakan suasana pembelajaran yang menyenangkan, menantang, serta membuat siswa berpikir kritis dan kreatif dalam mengajukan dan memechkan masalah-masalah. Hasil analisis respons siswa menunjukkan bahwa pembelajaran matematika dengan $P B L-$ PPS dapat mengubah siswa menjadi lebih tertarik dalam pembelajaran matematika. Sebagaimana ditunjukkan dari skor rata-rata aspek 11 yaitu 3,60 yang berada pada kategori positif, siswa setuju jika pembelajaran matematika pada pokok bahasan selanjutnya menggunakan $P B L-P P S$. Hal mengingikasikan Model $P B L-P P S$ dapat mengubah citra siswa dari yang takut akan pelajaran Matematika 
menjadi senang dengan pelajaran Matematika. Dari Matematika yang membosankan menjadi matematika yang menarik, sehingga bukan tidak mungkin minat dan motivasi belajar siswa dapat meningkat terhadap pembelajaran Matematika.

Berdasarkan Hasil analisis statistik deskriptif menunjukkan bahwa tingkat keterlakasanan pembelajaran, hasil postest, nilai gain, aktivitas siswa, dan respons siswa telah memenuhi kriteria kefektifan model $P B L$ $P P S$. Kriteria ketuntasan siswa juga telah memenuhi kriteria dengan persentase $87,9 \%$ melebihi $85 \%$ dari yang telah ditetapkan. Selanjutnya, hasil analisis statistik inferensial dengan menggunakan uji satu sampel (one sample $t$ test) menunjukkan bahwa kedua Ho ditolak yang menyatakan bahwa hasil belajar matematika siswa kelas X SMA Negeri 17 Makassar setelah diajar menggunakan model $P B L-P P S$ mencapai Kriteria Ketuntasan Minimal. Begitupun dengan peningkatan Hasil belajar matematika (Gain ternormalisasi) siswa kelas X SMA Negeri 17 Makassar setelah diajar menggunakan model PBL-PPS minimal berada pada kateagori sedang. Berdsarkan Kriteria keefektifan yang telah ditetapkan baik secara deskriptif maupun inferensial, model PBL-PPS efektif untuk indikator hasil belajar, aktivitas siswa, dan respons siswa.

\section{ACKNOWLEDGEMENT}

Ucapan terima kasih ditunjukan kepada Direktorat Riset dan Pengabdian Masyarakat, Deputi Bidang Penguatan Riset dan Pengembangan, Kementerian Riset, Teknologi / Badan Riset dan Inovasi Nasional Republik Indonesia yang telah membiayai keseluruhan biaya penelitian dalam skema Penelitian Dosen Pemula (PDP)

\section{KESIMPULAN \& SARAN}

\section{Kesimpulan}

Berdasrkan hasil penelitian dan pembahasan, maka kesimpulan yang diperoleh adalah sebagai berikut:

1. a. Rata-rata skor hasil belajar (posttest) yang diajar menggunakan Model Problem based Learning dengan Pendekatan Problem Posing-Solving mencapai 78,93 dari skor ideal 100 dengan standar deviasi 12,5 melebihi Kriteria Ketuntasan Minimal yang ditetapkan (70). Peningkatan hasil belajar berada pada kategori minimal sedang dengan rata-rata mencapai 0,75 dari skor ideal 1 .

b. Aktivitas siswa selama menggunakan Model Problem based Learning dengan Pendekatan Problem PosingSolving berada pada kategori baik dengan skor rata-rata mencapai 3,18 dari skor 4.

c. Respons siswa setelah diterapkan Model Problem based Learning dengan Pendekatan Problem PosingSolving berada pada kategori positif dengan skor rata-rata siswa mencapai 3,6 dari skor 4

2. Model Problem based Learning dengan Pendekatan Problem Posing-Solving efektif untuk indikator Hasil Belajar, Aktivitas Siswa, dan Respons Siswa

\section{Saran}

Berdasarkan kesimpulan yang dikemukakan, perlu diadakan penelitian lebih lanjut mengenai penerapan PBL-PPS dengan tatap muka secara langsung baik pada pokok bahasan yang sama maupun pada pokok bahasan berbeda, sekolah berbeda ataupun pada mata pelajaran lainnya.

\section{DAFTAR PUSTAKA}

Amiluddin, R., \& Sugiman, S. (2016). Pengaruh problem posing dan PBL terhadap prestasi belajar, dan motivasi belajar mahasiswa pendidikan matematika. Jurnal Riset Pendidikan Matematika, 3(1), 100-108. https://doi.org/10.21831/jrpm.v3i1.730 3

Aras, L., \& Juhari, A. (2020). The Influence of REACT learning strategies on mathematics learning outcomes and learning activities of fifth grade students at SDN Lariangbangi Makassar. Daya Matematis: Jurnal Inovasi Pendidikan Matematika, 8(1), 32-39.

Dafik, H. S., \& Lestari, N. D. S. (2014). Soal matematika dalam PISA kaitannya dengan literasi matematika dan keterampilan berpikir tingkat tinggi. Prosiding Seminar Nasional Matematika, 19.

Fogarty, R. (1997). Problem-based learning and other curriculum models for the 
multiple intelligences classroom. ERIC.

Herawati, O. D. P., Siroj, R., \& Basir, D. (2010). Pengaruh pembelajaran problem posing terhadap kemampuan pemahaman konsep matematika siswa kelas xi ipa sma negeri 6 palembang. Jurnal Pendidikan Matematika, 4(1).

Hudojo, H. (2005). Pengembangan kurikulum dan pembelajaran matematika. Malang: UM Press.

Ibrahim, M., \& Nur, M. (2000). Pengajaran Berdasarkan Masalah. Pusat Sains dan Matematika Sekolah. Program Pascasarjana UNESA: University Press.

Kurniati, D., Harimukti, R., \& Jamil, N. A. (2016). Kemampuan berpikir tingkat tinggi siswa SMP di Kabupaten Jember dalam menyelesaikan soal berstandar PISA. Jurnal Penelitian Dan Evaluasi Pendidikan, 20(2), 142-155.

Sari, V. (2007). Keefektifan Model Pembelajaran Problem Posing Dibanding Kooperatif Tipe CIRC (Cooperative Integrated Reading and Compotition) pada Kemampuan Siswa Kelas VII Semester 2 SMP Negeri 16 Semarang dalam Menyelesaikan Soal Cerita Materi Pokok Himpunan Tahun Pelajaran 2006/2007 [PhD Thesis]. Universitas Negeri Semarang.

Shanti, W. N., \& Abadi, A. M. (2015). Keefektifan pendekatan problem solving dan problem posing dengan setting kooperatif dalam pembelajaran matematika. Jurnal Riset Pendidikan Matematika, 2(1), 121-134.

Sutiarso, S. (2000). Problem Posing, Strategi Efektif Meningkatkan Aktivitas Peserta Didik dalam Pembelajaran Matematika. Journal Pengajaran Matematika, 6.

Trianto, M. P. (2009). Mendesain model pembelajaran inovatif-progresif. Jakarta: Kencana.

Wardhani, S. (n.d.). dkk. 2010. Pembelajaran Kemampuan Pemecahan Masalah Matematika Di SD.
Widodo, T., \& Kadarwati, S. (2013). Higher order thinking berbasis pemecahan masalah untuk meningkatkan hasil belajar berorientasi pembentukan karakter siswa. Jurnal Cakrawala Pendidikan, 5(1).

Xia, X., Lu, C., \& Wang, B. (2008). Research on mathematics instruction experiment based problem posing. Journal of Mathematics Education, 1(1), 153163. 